\title{
Do krajiny za land-artem
}

\section{Hana Kolářová}

Envigogika 8 (3) - Inspirace (Nerecenzované články)/ Inpiration (Non-reviewed articles)

Publikováno/published 15. 10. 2013

http://dx.doi.org/10.14712/18023061.395

\section{Abstrakt}

Recenze knihy: Tereza Hejtmánková, Michaela Hưrková, Alžběta Trojanová a Marcela Veselá: Do krajiny za land-artem. Vydalo Středisko ekologické výchovy a etiky Rýchory - SEVER v roce 2013, ISBN 978-80-86838-45-8.

Autorky zavedou čtenáře do "umění v krajině"; ukazují, jak se v něm pohybovat, jak si ho užít a jak k tomu pomoci dalším.

\section{Abstract}

Review of the book: Tereza Hejtmánková, Michaela Hůrková, Alžběta Trojanová a Marcela Veselá: Do krajiny za land-artem. Published by "Středisko ekologické výchovy a etiky Rýchory - SEVER" in 2013, ISBN 978-80-86838-45-8.

The authors introduce readers to "art in the landscape", show how it works, how to enjoy it and how to help others work with it.

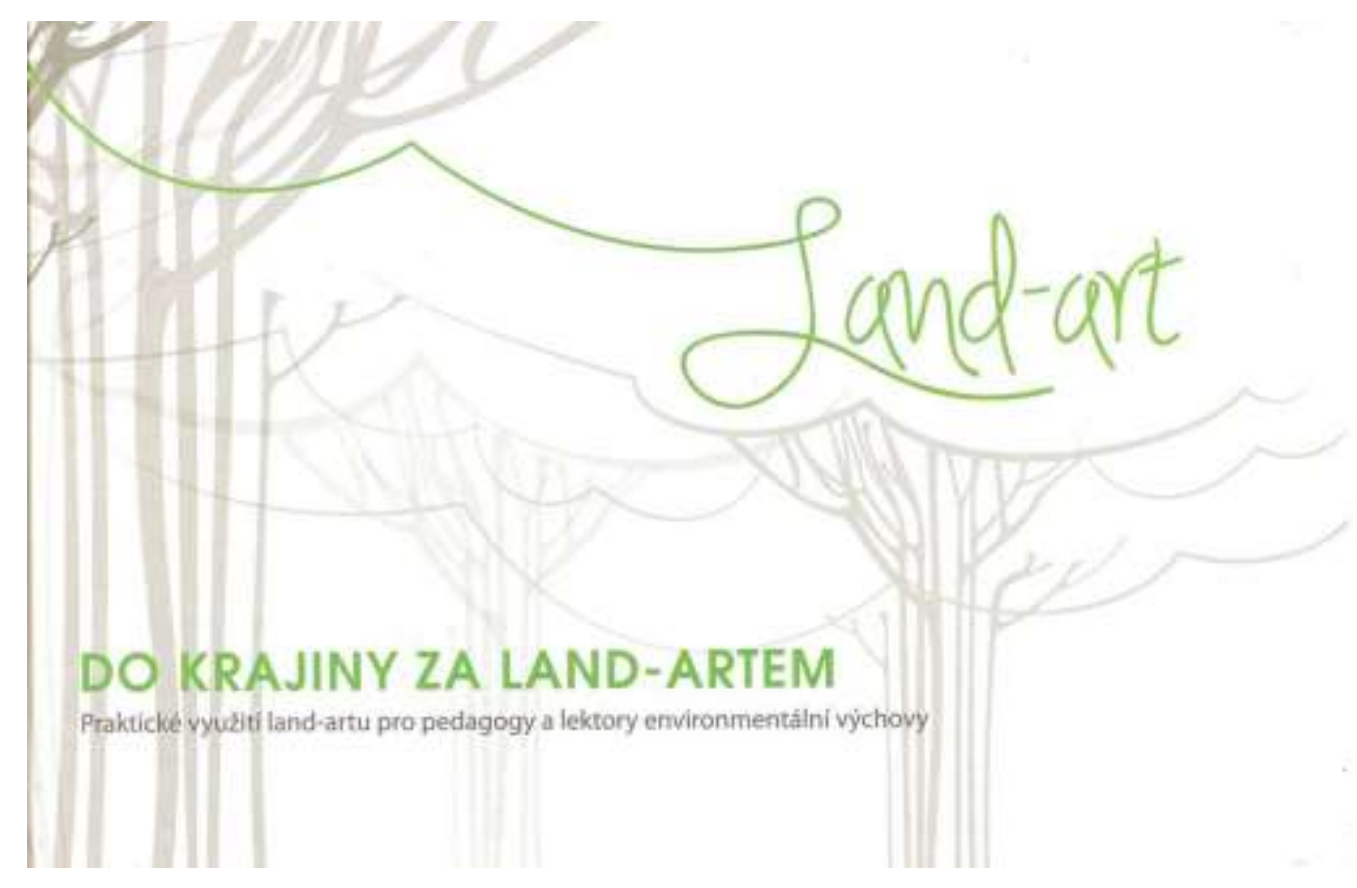


Pamatujete si ještě, jak jsme stavěli v lese domečky a zahrádky z mechu, klacíků, kamínků, trávy a listí? Nebo jak jsme tvarovali vlastním tělem anděla ve sněhu, stavěli sněhuláka, pletli věnce ze sedmikrásek nebo plochým oblázkem malovali řadu kruhů na vodní hladinu? Stále nové generace spontánně tvoří takové objekty, které dřive či později pohltí čas nebo ho rozmetají živly. Ano, i to je land-art.

Hlouběji do této části „umění v krajině" čtenáře zavedou Tereza Hejtmánková, Michaela Hưrková, Alžběta Trojanová a Marcela Veselá v publikaci „Do krajiny za landartem". Ukážou, jak se v něm pohybovat, jak si ho užít a jak k tomu pomoci dalším. Daly si záležet - textu budete dobře rozumět.

Svého druhu jedinečná publikace, pravděpodobně nejen v českém jazyce, představuje praktické využití land-artu (především) pro pedagogy a lektory environmentální výchovy. Seznámí přesněji s tím, co land-art je, jaké jsou jeho principy. Stručně, poučeně, v dobrém výběru autorky provedou čtenáře nedlouhou historií land-artu od nákladných monumentů Michaela Heizera, které si vyžádaly ekologicky problematický přesun tisíců tun kamení a písku, až po duchovně pokorné obrazce a objekty ze stébel či ledu Andyho Goldsworthyho, neodvratně určené ke „zkáze" v řádu hodin.

Autorky nám otevírají dveře tam, kde je prožitek umělecké činnosti přístupný bez velkých nároků na pomůcky, znalosti či dovednosti. Dokonce $v$ nás tato tvorba-hraní $s$ největší pravděpodobností vyloudí leccos, o čem jsme ani netušili, že to v sobě máme. A zároveň se prostřednictvím této aktivity bezbolestně učíme: pozorovat zákonitosti prírody, trpělivosti při hledání kýženého tvaru, tvořivé improvizaci i promýšlení, spolupráci a vnímání druhých při interpretaci vlastního díla, lepšímu chápání kontextu našeho bytí.

Na praktických radách pro lektory je v publikaci patrná dobrá metodická příprava autorek a zkušenost. Na základě moderních pedagogických přístupů, jako je například tř́fázový model učení E-U-R (evokace - uvědomění - reflexe), vedou čtenáře z řad pedagogů k tomu, jak využívat široké možnosti land-artu. Uplatní se ve formě jednoduchých aktivit, které sblíží účastníky hodiny či kurzu, těch, které mají vést k motivaci, naladění a propojení odlišných aktivit, či naopak odreagování, anebo jako několikahodinová tvorba ve skupině či individuální tvorba intimnějších i monumentálnějších artefaktů. Dokonce se nabízí možnost zařadit do této kreativní činnosti jako její součást pohybové hry; stále však v souladu s charakterem místa a s šetrností k prrírodě, což zde rozhodně není v rozporu s lidskou tvorbou, ba naopak. Člověk a přírodní procesy se stávají partnery, spolutvůrci.

Jádro publikace představují př́klady autorských workshopů, které jsou skutečně vyzkoušené. Doprovázejí je autentické fotografie. Popis dílen nezanedbává žádnou fázi: od organizačního zákulisí přes seznámení účastníků, podporu jejich odvahy k tvorbě, postup společného výběru jednotícího tématu, ukázky motivačních textů, stylové rozdělení účastníků do skupin, komentář k výběru plátna - pardon, místa v krajině -, různá pojetí tématu a poznámky k průběhu vlastní tvorby až po závěrečnou "galerii" a společnou interpretaci děl. „Právě sdílení myšlenek a zážitků z tvorby je často nezapomenutelným prožitkem skupinové práce..." uvádějí autorky svou zkušenost ze skupinové dílny v př́rodě na dané téma. Obdobně přehledně odhalují průběh skupinové land-artové hry s prírodou, v přírodě a v rytmu přírody, a průběh workshopu věnovaného individuální tvorbě, při níž účastníci-tvưrci prostřednictvím svého díla například poukáží na zajímavý bod v krajině. Tím se zapojují do psaní př́běhu krajiny, podtrhují její genius loci. Jejich dílo tu možná nějaký čas zůstane, je-li z kamenů, nebo naopak si mohou land-artoví umělci hlouběji vědomě přivodit náročnější prožitek: smyslu proměn a pomíjivosti. 
Na závěr $v$ knížce dostane čtenář dobrou nabídku: tipy na vzdělávací instituce, které poskytují vedení ekologicky citlivých programů land-artu $v$ různém časovém rozsahu, od jednotlivých výukových programů, přes víkendové workshopy až po delší pobyty, jejichž součástí takové dílny jsou. Nechybí ani dobře vybraný přehled literatury a internetových odkazů. Možná by se $v$ něm mohl objevit ještě př́mý odkaz na slavný, působivý dokumentární film Rivers and Tides. Čtenáře by také zřejmě zajímalo aspoň pár slov o autorkách, což v publikaci nenajdou. Ocenit je třeba dobře strukturovaný, logicky řazený text bez chyb, což není v současnosti vždy pravidlem.

Grafická úprava působí př́jemně a je přehledná. Fotografie, které jsou její podstatnou vypovídací a inspirativní součástí, mají dostatek prostoru. Řadu podnětných myšlenek zdůrazňuje umístění jediné věty na celou stránku. Šarm knížce dodává i podlouhlý formát "na šířku", korespondující s myšlenkou na krajinu. Použité fotografie jsou dokumentární, možná by si však právě takováto knížka zasloužila v tomto ohledu větší osobitost. To může být námět pro další vydání, až tato podnětná publikace bude rozebraná. Poslouží totiž dobře jak ve školách, dalších vzdělávacích nebo volnočasových institucích, tak jako inspirace $v$ rodinách $s$ dětmi, vícegeneračních rodinách nebo $i$ dospělým středního věku $v$ plném nasazení jako zdroj námětů pro aktivní odpočinek a obohacení osobního života sebevyjádřením $v$ kterémkoli ročním období. Zkrátka, může potěšit každého citlivého čtenáře se smyslem pro umění a př́rodu.

Vydalo Středisko ekologické výchovy a etiky Rýchory - SEVER v roce 2013, ISBN 978-80-86838-45-8. Publikace vyšla díky programu Thing Big.

\section{Hana Kolářová}

Redaktorka na volné noze se zaměřením na životní prostředí, momentálně též šéfredaktorka časopisů Bedrník a U nás - Libuš a Písnice.

hana.kolarova@tiscali.cz 